\title{
Terénní výuka ve formálním vzdělávání
}

\section{Jan Činčera, Jakub Holec \\ Envigogika 11 (2) - Recenzované články/ Reviewed Papers}

Published/ Publikováno 16. 12. 2016

DOI: $\underline{10.14712 / 18023061.533}$

\begin{abstract}
Abstrakt
Text shrnuje výsledky více než 70 studií analyzujících dopady terénních programů formálního vzdělávání na žákovské znalosti, postoje, dovednosti, přesvědčení a chování. Objevili jsme převažující množství prací dokládající přínosy terénních programů a to jak v absolutním smyslu tak relativně $v$ porovnání $s$ programy $v$ učebně. Nejdůležitější bariérou většího rozšíření terénní výuky se zdá být koncept terénní výuky zastávaný učiteli a vedením školy. $V$ rámci studie doporučujeme „rozmazaný" př́stup, který by přirozeně propojoval výuku $v$ učebně s výukou $v$ terénu a maximalizoval tak její dopad na žáky.
\end{abstract}

\section{Klíčová slova}

Terénní výchova, místně zakotvené učení, školní zahrady, komunitní projekty, terénní práce, pobytové programy

\begin{abstract}
The study summarizes the results of more than 70 studies analyzing the impact of outdoor formal education programs on students' knowledge, attitudes, skills, beliefs, and behavior. We found a prevailing evidence of the benefits of outdoor programs, in both an absolute sense and relative to indoor lessons. The most significant barrier to extending outdoor formal education programs we identified was the concept of outdoor education as it is perceived by school teachers and administrators. In the study, we call for a "blended" educational approach merging indoor and outdoor educational settings to maximize the impact on students.
\end{abstract}

\section{Key words}

Outdoor education, place-based education, school garden, community projects, field study, residential programs 


\section{Úvod}

Složitá realita současného světa přináší specifické výzvy i pro české školství. Jednou z nich je i možnost rozšíření formální výuky za hranice "zdí" školy a její propojení se světem „vně". "Terénní výuka" současně představuje zajímavý a nejednoznačný fenomén, přinášející specifické terminologické, metodologické i praktické problémy. Na některé z nich bychom rádi reagovali i v předkládané studii.

Podle Hofmana et al. (2011) je terénní výuka „komplexní výuková forma zahrnující rưzné vyučovací metody, mezi něž patří např́klad pozorování, pokus, projektová metoda, kooperativní metody a metody zážitkové pedagogiky. Z hlediska organizační formy výuky se $v$ rámci terénního vzdělávání uplatňují především terénní cvičení, vycházky do přírody, exkurze, tematicky zaměřené výlety a expedice, přičemž smysl takové výuky spočívá především v práci žáků v terénu, tedy mimo školu“ (s. 310-311). Podle Brodina (2009) se terénní výuka uplatňuje jako doplněk ke klasickému vyučování ve školní třídě.

Ačkoliv terénní výuka je v našem vzdělávacím systému dlouhodobě nahlížena jako jedna z forem výuky uplatňované především v přírodovědných předmětech, $v$ českém pedagogickém výzkumu stále chybí studie, které by se terénní výuce systematicky věnovaly s dưrazem na zhodnocení možných přínosů pro kognitivní, afektivní a psychomotorický vývoj žáka. Cílem této studie je prostřednictvím analýzy dostupných zdrojů poskytnout co nejkomplexnější přehled prací, které se zabývají hodnocením terénní výuky a jejích možných přínosů pro vzdělávání dětí a mladých lidí.

V rámci studie bude „terénní výuka“ chápána jako takové aktivity a programy, které jsou součástí formálního vzdělávání žáků a odehrávají se mimo vnitřní prostory školy. Takové pojetí značně rozšiřuje záběr naznačený Hofmanem et al. (2011) a přináší nutnost analyzovat teoretické diskursy, ve kterých jsou určité aspekty takto chápané terénní výuky realizovány. Podobný přístup prezentuje i metastudie zpracována Rickinsonem et al. (2004), která se zaměřuje na tři související, ale odlišné diskursy: terénní exkurze, školní zahrady a outdoorovou (dobrodružnou) výchovu. $\checkmark$ naší studii vyjdeme částečně z tohoto přístupu a budeme zkoumat především následující oblasti:

- Školní zahrady a využití školních pozemků;

- $\quad$ Adaptační kurzy, školy v přírodě a další programy zaměřené na rozvoj vztahů ve třídě;

- Místně zakotvené učení a komunitně orientované projekty;

- Přírodovědně zaměřené terénní exkurze a programy organizované školou;

- Krátkodobé a pobytové programy organizované externími subjekty.

Je třeba upozornit, že každá kategorizace přináší svoje rizika. Alternativní přístup, při kterém by studie vycházela například z typologie vzdělávacích cílů (kognitivní, afektivní, konativní) by při situaci, kdy jeden program často usiluje o dosažení cílů ve všech těchto kategoriích, nutně vedla k značné míře obsahové redundance. Členění podle forem, organizace či metod výuky by vedlo k ignorování reality, ve které metody, formy a organizace neexistují odděleně, ale vytváři komplexní celek. Zvolený přístup je na druhou stranu nutně poněkud arbitrární a vycházející spíše z autory reflektované praxe, než apriorně stanovené teorie.

Problematikou využití školních zahrad ve výuce se v poslední době zabývá rostoucí počet prací. I v domácím kontextu prochází využití školních zahrad v poslední době značným rozvojem a to jak kvantitativním, tak v oblasti jejich pojetí (Vácha, 2015). Značnou zásluhu na tom mají i centra environmentálního vzdělávání (zejména Chaloupky, Lipka), které k této problematice začaly vydávat metodické materiály (Burešová, 2007) a začaly organizovat konference, semináře a konzultace. Myšlenkovým východiskem je přesvědčení o využití školních zahrad pro zdravý rozvoj žáků a jejich environmentální a prrírodovědné kompetence (Fisher-Maltese \& Zimmerman 2015). 
Jako „adaptační kurzy" zde budeme chápat pobytové programy, jejichž cílem je adaptace žáků na nové prostředí. Kurzy typicky obnáší alespoň jednu noc strávenou mimo domov i školu, zpravidla vycházejí z metodiky zážitkové pedagogiky (dobrodružné výchovy) a obvykle se soustřed'ují na práci s uzavřenou skupinou jedné třídy (Bell et al., 2014; Žák, 2011). Specificky českým rysem jsou tzv. školy $v$ přirodě, ve kterých žáci tráví jeden až dva týdny $v$ prírodním prostředí a kombinují výuku s aktivitami na posilování sociální koheze (Smetáčková, 2011). Na rozdíl od adaptačních kurzů nejsou školy $v$ prírodě zaměřeny primárně na adaptaci žáků na nové prostředí a prvotní utváření vztahů ve skupině, ale spíše na posilování vztahů v již zformované skupině. Celá oblast čerpá především z diskursu "výchovy v přírodě" (outdoor education). Základním východiskem "výchovy v prírodě" je snaha převést výuku z učeben do př́rodního prostředí. Výchova $v$ př́rodě se pak soustředí bud' především na sociální a osobnostní kompetence (jedním z metodických př́stupů je např. tzv. dobrodružná výchova), nebo na formování vztahu k přírodě a environmentálnímu porozumění (pak je často použiván pojem outdoorová a environmentální výchova) (Priest, 1986; Nicol, 2003; Priest \& Gass, 2005). V českém kontextu problematiku vývoje a rozšíření výchovy v prírodě mapoval např́íklad Neuman (2013).

Diskurs místně zakotveného učení (place-based education) se do českého prostředí dostal poměrně nedávno, díky iniciativě center environmentálního vzdělávání (SEVER, Nadace Partnerství). J eho principem je propojování školní výuky s místní komunitou. Metodicky čerpá především z projektové výuky a tzv. servisní výuky - aktivit zaměřených na konkrétní pomoc lokalitě (service learning). Žáci se tedy učí tak, že samostatně zkoumají místní komunitu a podle situace podnikají akce na řešení jejích problémů. Terénní výuka se může objevit ve všech fázích výuky - například při vstupním společném mapování místních problémů, sběru dat i při závěrečné prezentaci výstupů komunitního projektu (Sobel, 2005; Duffin et al., 2006; Smith, 2007; Gruenewald, 2008). Programy místně zakotveného učení zpravidla cílí na široké spektrum žákovských kompetencí a specificky na posilování jejich vztahu k místu. Související přístupy, využívající propojení školní výuky s místní komunitou se u nás objevovaly i nezávisle na diskursu místně zakotveného učení, např. v rámci výuky geografie (Trávníček, Trojan, Svozil, \& Hynek, 2013).

Pobytové programy, at' již jsou organizovány samotnou školou, či externím subjektem, jsou zpravidla zaměřeny na výuku prírodních věd či na environmentální výchovu. Jejich samotné provedení pak může vycházet z celé řady metodických př́stupů, jako je badatelsky orientovaná výuka (inquiry-based learning) (Dostál, 2015), integrovaná tematická výuka (Kovalik \& Olsen, 1994), učení v opravdovém světě (The Real World Learning, 2015), výchova o Zemi (van Matre, 1999) a další. Organizačně jde bud' o programy, které se celé odehrávají mimo prostředí školy, nebo kombinují pobyt $v$ centru a terénu $s$ předchozí a navazující prací ve škole (přestože tento typ programu není tedy čistě pobytový, v domácím diskursu pro něj zatím neexistuje vhodný pojem).

Celkově Ize říct, že problematika terénní výuky je velmi široká a jakýkoliv pokus o její analýzu bude nutně pouze orientační.

\section{Metodologie}

Ve studii se snažíme odpovědět na následující otázky:

- Jaké jsou přínosy terénní výuky pro naplňování cílů školního kurikula?

- V jakých oblastech je terénní výuka účinnější, než výuka realizovaná ve školním prostředí?

- Jaké jsou bariéry častějšího zařazování terénní výuky na školách?

Pro nalezení odpovědí na uvedené výzkumné otázky jsme volili formát metastudie. Cílem bylo najít a excerpovat publikace, které splňovaly následující kritéria:

- Byly publikovány $v$ zahraničních či domácích recenzovaných odborných časopisech; 
- Tematicky korespondují s diskursem terénní výuky;

- Obsahují původní empirický výzkum či metastudii založenou na analýze jiných výzkumných prací.

Vyhledávali jsme v běžných akademických zdrojích, tj. zejména v elektronických zdrojích dostupných na Masarykově univerzitě Brno (např. EBSCO, PROQUEST, ERIC, JSTOR, Sage, Science Direct, Springer, Wiley), volně dostupných informačních zdrojích (Google for Scholars) a dalších zdrojích dostupných členům autorského týmu (ResearchGate). Pro vyhledávání byla použita klíčová slova "outdoor", "place-based education“, „community project“, "farm education“, "residential program“, v kombinaci s "education" či "school”. I přes uvedený záběr a předpokládané pokrytí problematiky nelze vyloučit, že by použití dalších pojmů (např. "fieldwork", "field-study“, field education) mohlo přinést další výsledky. Další rozšíření zdrojové základny by pak přineslo zahrnutí i jiných, než časopiseckých zdrojů. Po uvážení jsme na tento problém reagovali zařazením některých reprezentativních přehledových studií, pakliže splňovaly ostatní dvě podmínky.

$\checkmark$ textu se zaměřujeme na hodnocení účinnosti, resp. efektivity (effectiveness), tj. hodnocením míry, s jakou program dosáhl svých očekávaných výstupů. Z pragmatických důvodů se naopak nezabýváme otázkou úspornosti (efficiency) programu, tj. např́klad poměrem nákladů a prínosů (cost-benefit analysis) programu (Bennett, 1989; Činčera, 2010). Důvodem je marginální zastoupení studií zaměřených na úspornost ve vzdělávacím kontextu. Předpokládáme-li vyšší nároky terénní výuky na čas, přípravu či finanční zdroje, představoval by nicméně tento typ analýz důležitý príspěvek k tématu.

Po „ručním" prohlédnutí a filtrování se výsledek zúžil na přibližně 70 studií. Ty se staly základem pro další analýzu. $V$ analýze byl použit kvalitativní přistup. $V$ nalezených studiích jsme identifikovali společné motivy, které jsme porovnávali s výsledky nalezených metastudií, a které dále prezentujeme. Použitý design si neklade nároky na úplnost pokrytí tématiky. Domníváme se, že záběr terénní výuky je natolik široký, že taková úplnost není možná. Předpokládáme ale, že i stávající míra sycení jednotlivých motivů je dostačující pro nalezení odpovědí na položené výzkumné otázky.

\section{Výsledky}

\section{Školní zahrady a využití školních pozemků}

Využití školních zahrad nabízí podle některých autorů velkou príležitost pro výuku prírodních věd (Rye et al., 2012). Vybavenost českých škol zahradou či pozemkem bylo předmětem několika průzkumů. Podle studie SSEV Pavučina (2009) provedené na vzorku 829 škol disponovalo 90 procent škol určitou formou pozemku, 23 procent pak prírodní učebnou. Podle studie Váchy (2015) na vzorku 119 škol disponovalo zahradou 72 procent škol. Podle průzkumu Činčera et al. (in press) disponuje pozemkem 81 procent ze vzorku 645 škol, 73 procent pak školní zahradou či prírodní učebnou. Výhodou využívání školních zahrad vzhledem k ostatním možnostem realizace terénní výuky je snadná dostupnost výuky na zahradě jak pro učitele, tak i pro žáky (Passy, 2014). I přes dílčí rozdíly je zjevné, že školní zahrady představují nejdostupnější možnost propojení školní výuky s venkovním prostředím.

Podle průzkumu Nadace Karla Komárka Proměny (2016) jsou školní zahrady školami nejčastěji využívaným přírodním prostredím, pro výuku byly využívány na zhruba šesti procentech škol. Samotná forma využívání může být velmi různorodá a zahrnovat pomoc se zahradnickými pracemi, výuku v přírodní učebně či zapojení žáků do samotného plánování školních zahrad (Christidou et al., 2013; Cincera \& Kovacikova, 2014).

Podle Christidou et al. (2013) představuje právě zapojování žáků do plánování zahrad značný potenciál, protože žáky podle něj samotné zahradnické práce př́liš nelákají. Dospělí také často plánují školní zahradu bez ohledu na potřeby žáků, tj. příliš je organizují, uspořádávají a zabezpe- 
čují, což žáci, kteří by preferovali prostor pro spontánní hru, vnímají negativně (Thomson, 2007; Mallone \& Tranter, 2004).

Podle Skinnera et al. (2012) je pro motivaci žáků účastnit se zahradnických prací důležitá pocitóvaná autonomie. $V$ českých podmínkách má ale prostor pro samostatnější rozhodování o zahradě pouze pětina žáků, ostatní ve větší či menší míře vykonávají instrukce dané učitelem (Činčera et al., in press).

Vliv programů využívajících školní zahrady byl předmětem několika studií. Podle metastudie Rickinsona et al. (2004) vykazují účastníci školních zahradních programů posun v osobnostní oblasti (větší sebejistota, odpovědnost), sociálních vztazích ve škole, motivaci k učení, vztahu k místní komunitě, zdravotní kondici a stravovacích návycích. Blair (2009) na základě porovnání několika starších studií předpokládá, že zahradnické aktivity mají pozitivní dopad na stravovací návyky žáků a na jejich znalosti prírodních věd. Za nepotvrzené považuje dopady na environmentální postoje či sociální chování žáků.

$\mathrm{S}$ těmito zjištěními částečně korespondují některé navazující výzkumy. Pozitivní dopady zahradnických prací na výuku př́rodních věd zjistili např. Fleszar \& Szczesna (2009), jejich studie ale stojí spíše na reflexích studentských prací, než vlastním výzkumu. Parmer et al. (2009) zaznamenali, že žáci, kteří se účastnili zahradnických prací, změnili svoje stravovací návyky a posílili konzumaci zdravé stravy a zeleniny. Ruiz-Gallardo, Verde a Valdés (2013) na výzkumu vlivu zahradnické práce na skupinu žáků středních škol s kázeňskými a studijními problémy zjistili snižení počtu incidentů problémového chování ve škole, nárůst sebevědomí žáků a snížení počtu případů jejich studijního neúspěchu v důsledku účasti na programu. Cincera a Kovacikova (2014) objevili u žáků, kteří se v rámci zapojení do programu Ekoškola účastnili navrhování školního pozemku, silné přesvědčení o vlastní schopnosti pozitivně ovlivňovat stav okolního prostředí. Fisher-Maltese a Zimmerman (2015) nezjistili průkazný dopad zahradnických prací na postoje žáků, dílčí změna postojů byla ale patrná z rozhovorů s žáky. Plaka a Skanavis (2016) objevili, že účast žáků na zahradnickém programu posílila jejich environmentální vědomí, ekologické znalosti a pozitivně změnila jejich stravovací návyky.

Celkově můžeme shrnout, že využití školních zahrad ve výuce přináší potenciálně pozitivní dopady na zdravý životní styl žáků a vzájemné vztahy ve třídě, může mít dále vliv na znalosti, postoje a přesvědčení žáků. Důležitou roli patrně hraje forma zapojení žáků, přičemž poskytnutí prostoru k realizaci vlastních návrhů na vybavení zahrady žáky pravděpodobně více motivuje a zvyšuje efekt tohoto typu terénní výuky na žáky.

\section{Místně zakotvené učení a komunitně orientované projekty}

Pro výzkum programů, které se hlásí k diskursu místně zakotveného učení, byly zpravidla využity kvalitativní výzkumné metody. Výzkumy se proto soustředí více na proces učení, než na jeho výsledky. Analýza procesů často poukazuje na témata a motivy, které se $v$ průběhu programů vynořují. Harrison (2011) uvádí témata, jako je motiv "někam patřit", „péče o místo" a další. Posilování vztahu k místu se objevuje i v dalších studiích (Semken, 2005). Ontong a Grange (2015) ukazují, jak se žáci i učitelé jihoafrického programu konfrontovali s motivy politické nerovnosti a existujících sociálních křivd, které měnily způsob, jakým vnímali svoji komunitu.

Další autoři předpokládají přínos programů místně zakotveného učení na rozvoj sociálních a osobnostních kompetencí. Podle Athmana a Monroe (2004) programy místně zakotveného učení rozvíjejí kritické myšlení žáků, odpovědnost a přesvědčení o schopnosti zvládat řešené problémy. Předpokladem je ale dostačující autonomie žáků a jejich odpovědnost za realizovaný projekt a propojování aktivit s reálným světem. Powers (2004) uvádí, že programy místně zakotveného učení jsou velmi vhodné pro učení žáků se speciálními vzdělávacími potřebami. Programy posilují jejich osobnostní kompetence, vztah s komunitou i motivaci k učení. Pozitivní vliv na posilování kooperativních a dalších dovedností (např. plánování) uvádí i další autoři (Mannion, Fenwick \& Lynch, 
2013; Motallebzadeh, 2014). Ceaser (2012) doložil vliv kriticky orientovaného komunitního programu na posílení empowermentu žáků a jejich odhodlání k proenvironmentálnímu chování.

Dlouhodobé dopady programů místně zakotveného učení zkoumali ve své metastudii 190 různých programů Johnson, Duffin a Murphy (2012). Podle jejich výsledků téměř polovina zkoumaných programů zaměřených na kvalitu ovzduší skutečně vedla k přijetí opatření na zvýšení kvality ovzduší a v důsledku ke zlepšení situace. Největší účinnost měly programy, které obsahovaly prvky partnerství s komunitou a aktivní zapojení žáků do pomoci lokalitě. Úspěšné programy zpravidla obsahovaly komunitní projekt, řešily lokální problém a měly podporu vedení školy. Úspěšné programy dále byly $v$ určité míře řízeny samotnými studenty, vycházely z jejich zájmu a studenti $\checkmark$ nich měli možnost reflektovat svoji práci.

Domácí studie programů místně zakotveného učení jsou zatím zastoupeny jen okrajově (Cincera, Johnson, \& Kovacikova, 2015). Podle průzkumu Činčery et al. (in press) se pouze na dvaceti procentech základních škol žáci zapojují do projektů na zkoumání místní problematiky životního prostředí a na přibližně stejném počtu škol do projektů, ve kterých pomáhají místní problémy řešit. Pokud se takové projekty na školách realizují, jsou často řizeny učitelem a žáci hrají spíše pomocnou úlohu (Činčera et al., in press).

Celkově můžeme shrnout, že programy místně zakotveného učení představují důležitou oblast terénní výuky s potenciálním dopadem na posilování vztahu žáků ke své komunitě a rozvoj jejich sociálních dovedností. V České republice jsou ale takové programy dosud zastoupeny jen poměrně málo, a pokud ano, často nejsou realizovány optimálním způsobem.

\section{Pobytové a kombinované programy organizované školami a dalšími subjekty}

Zapojení pobytových akcí, tedy programů, ve kterých se žáci účastní výuky v prírodním prostředí za hranicemi školního pozemku, představuje asi nejtypičtější formu terénní výuky. $V$ českých podmínkách takové programy realizuje téměř 90 procent základních škol, zhruba dvě třetiny škol pak nabízí žákům druhého stupně nejméně jednu pobytovou akci ročně (Činčera et al., in press). Vzhledem ke specifickým odlišnostem budeme dále rozlišovat mezi pobytovými programy, zaměřenými primárně na rozvoj vztahů ve tř́dě, prírodovědně zaměřenými programy organizovanými samotnými školami a programy organizovanými externími subjekty.

\section{Adaptační kurzy, školy v přírodě a další programy zaměřené na rozvoj vztahů ve tř́ídě}

Využití terénní výuky bývá často spojováno s př́nosem pro rozvoj sociálních vztahů ve třídě. Pozitivní prínosy programů dobrodružné výchovy na vztahy mezi žáky a mezi žáky a pedagogem byly doloženy $v$ několika studiích. Podle Rickinsona (2004) Ize na základě excerpovaných studií předpokládat, že tento typ programů posiluje u žáků jejich sebepojetí, přesvědčení o vlastní schopnosti řešit různé problémy (self-efficacy), rozvíjí jejich sociální dovednosti, povzbuzuje žádoucí chování (např. omezení záškoláctví) a posiluje jejich fyzickou zdatnost. Podle rozsáhlé studie Kendalla a Rogera (2015) zahrnující data z šedesáti skotských škol byly jako nejvýznamnější efekty pobytových programů vyhodnoceny jejich dopady na vztahy mezi žáky a vztahy mezi žáky a jejich učiteli. V českém prostředí se účinnost adaptačních kurzů stává často předmětem studentských prací, publikovaných studií existuje ale překvapivě málo.

Žák (2011) zkoumal relativní účinnost adaptačních kurzů pro první ročníky středních škol. Podle jeho výsledků přispívá účast na těchto kurzech k rozvoji pozitivního vnímání spolužáků. Účinek adaptačních kurzů je ale pouze krátkodobý a zhruba po půl roce se jejich efekt ztrácí.

Smetáčková (2011) zjistila, že každoročně se zhruba 20 procent českých žáků zúčastní školy $v$ prírodě. Za posledních pět let ale klesla průměrná délka pobytu v přírodě, a téměř 20 procent žáků z každé třídy se jej (nejčastěji z finančních důvodů) neúčastní. Podle Smetáčkové připisují učitelé školám v prírodě nejčastěji pozitivní vliv na stmelení kolektivu a posílení vztahů žáků s uči- 
teli. Tyto efekty jsou ale současně podrývány vysokým podílem neúčastnících se dětí a tendencí přenechávat organizaci akce externím subjektům.

Celkově můžeme předpokládat, že terénní programy zaměřené na posilování sociální koheze žáků ve třídě a jejich vztahu s učitelem pravděpodobně mohou plnit svoje očekávání, jejich efekt je ale $v$ českém kontextu málo doložený a ovlivněný konkrétními kontextuálními faktory.

\section{Přírodovědně zaměřené terénní exkurze a programy organizované školou}

Terénní výuka představuje v naší studii širokou kategorii, zahrnující jak programy, odehrávající se výlučně mimo prostory školy, tak programy, které jsou kombinací práce $v$ učebně a ve venkovním prostředí. Nalezené studie se zpravidla zaměřují na hodnocení dopadu programu na prírodovědné znalosti žáků a jejich postoje k přírodním vědám, případně na další související kompetence.

Podle Rickinsonovy (2004) metastudie má tento typ programů pozitivní dopady především na dlouhodobé upamatování se nových znalostí získaných v přírodě, osobní růst, sociální dovednosti, vzájemné posilování postojů a znalostí žáků. Pro úspěch programu je ale zásadní úroveň jeho metodické připravenosti. Úspěšnější bývají podle Rickinsona programy delší, s adekvátně řešeným vztahem mezi cíli a aktivitami, provázané se školním kurikulem, kombinující předchozí i následnou práci ve škole. K podobným závěrům dochází také Neil a Richards (1998). Podle jejich metastudie mají terénní programy pozitivní vliv na sociální a osobnostní kompetence žáků. Důležité jsou ale vlastnosti programu (zejména jeho délka) a dále osobnostní faktory na straně žáků. Důležitost kvality programu a jeho provázanosti se školní výukou uvádí také Orion a Hofstein (1994). Erdogan, Usak a Bahar (2013) ve své metastudii z tureckého prostredí konstatují, že prírodovědně zaměřené terénní programy mají pozitivní vliv na př́rodovědné znalosti a porozumění principům vědy, zatímco jejich vliv na postoje je spíše sporný.

Z dalších studií lze předpokládat, že žáci považují přírodovědně zaměřené terénní exkurze za zábavné a atraktivní (Hoffman \& Korvas, 2008; Nadelson \& Jordan, 2012) a přisuzují jim pozitivní dopad na vlastní environmentální kompetence (Nadelson \& Jordan, 2012).

Erdogan (2015) v evaluaci programu kombinující práci v terénu s výukou v učebně, návštěvou farmy a laboratorním zkoumáním, zjistil jeho efekt na posílení environmentálních znalostí, postojů, odhodlání i chování žáků. $V$ jiné evaluaci nalezl pravděpodobný dopad programu na chování žáků, přičemž dopad na znalosti a postoje zůstal nevýznamný (Erdogan, 2011).

\section{Krátkodobé a pobytové programy organizované externími subjekty}

Zdaleka nejčastějšími subjekty, se kterými školy spolupracují na zabezpečení terénní výuky, jsou centra environmentálního vzdělávání, které škole nabízejí krátké (několik hodin dlouhé), pobytové (několik dní dlouhé) či komplexnější tematicky orientované programy environmentální výchovy. $\vee$ českých podmínkách jsou ( $v$ kontextu environmentální výchovy) tato centra zdaleka nejčastějším typem partnerů, spolupráci s nimi uvedlo v průzkumu na 645 školách téměř 80 procent respondentů (Činčera et al., in press). Dalšími partnery nabízejícími terénní programy jsou např́ílad Lesy ČR, které organizují krátké výukové programy tzv. lesní pedagogiky. Učitelé jsou s kvalitou programů nabízených centry environmentálního vzdělávání zpravidla vysoce spokojeni. Nejčastěji si ale objednávají krátké, několik hodin trvající výukové programy, zatímco pobytové programy si objednávalo jen cca 16 procent ze vzorku 165 dotazovaných škol (Činčera, 2015).

Zejména pobytové programy bývají často předmětem evaluací, které zpravidla dokládají pozitivní efekty na environmentální znalosti či znalosti určité lokality, postoje i dovednosti žáků. Převažujícím formátem jsou studie založené na smíšené metodologii, kombinující dotazníky, testy, pozorování a rozhovory s účastníky.

Řada studií dokládá pozitivní vliv hodnocených pobytových programů na environmentální postoje, znalosti a chování (Rickinson, 2001). Vliv na znalosti, postoje a chování opakovaně doložili 
Dettmann-Easler a Pease (1999), Ferreira (2012), Manoli, Johnson a Hadjichambis (2014) a Bogner (Bogner, 1998; Bogner \& Wiseman, 2004), klíčovou proměnnou podle nich byla délka programu (za optimální považují pětidenní programy). Emmons (1997) zjistila pozitivní posun v environmentálních postojích, postojích ke konkrétním zvířatům, zájmu a empatii k životnímu prostředí. Palmberg a Kuru (2000) doložili vliv pobytového programu na posílení sebevědomí žáků, motivace účastnit se outdoorových aktivit, jejich empatie k př́rodě a environmentální odpovědnosti. Stern, Powel a Ardoin (2008) doložili dlouhodobý efekt pobytového programu na environmentální vědomí a krátkodobý na propojení žáků s prírodou a jejich zájem prrírodu zkoumat. Ve studii American Institute for Research (2005) byl zjištěn pozitivní vliv pobytového programu na schopnost žáků řešit konflikty a spolupracovat, zájem o životní prostředí a na environmentální chování.

Některé studie byly zaměřeny spíše procesně, například na obtíže s implementací kvalitativních norem do praxe environmentálního programu (Činčera, 2015). Další, domácí studie zjistily pozitivní dopad pobytových programů na vztah žáků k místu (Cincera, Johnson, \& Kovacikova, 2015), odhodlání k proenvironmentálnímu chování a postoje k ochraně prírody (Činčera, 2012), badatelské dovednosti (Činčera, 2011a) či environmentální postoje a chování (Činčera \& Macháčková, 2009; Činčera, 2011b; Johnson \& Cincera, 2015). Studie, dokládající relativní neúspěch programu ve snaze ovlivnit žáky jsou publikovány jen zř́́dka (Činčera, 2013), Ize ale předpokládat, že př́činou je nízká ochota publikovat studie s negativními výsledky.

Specifickou oblastí pak je účast škol na programech souvisejících s farmami. Přestože tato oblast dosud nebyla dostatečně výzkumně pokryta, Smeds et al. (Smeds \& Jeronen, 2011; Smeds, Jeronen \& Kurppa, 2015) zjistili, že účast žáků na tomto druhu programu posiluje jejich pozitivní postoje $\mathrm{k}$ farmářské práci a rozšiřuje jejich porozumění zemědělským činnostem na farmě.

Krátké, méně než jeden den dlouhé terénní výukové programy bývají jen zřídka předmětem hodnocení. Podle metaevaluace zpracované Zelezny (1999) trvaly programy s měřitelným vlivem na environmentální chování žáků déle než deset hodin, na faktor délky upozornily i další citované studie (Rickinson et al., 2004; Bogner, 1998; Bogner \& Wiseman, 2004). Několik studií zkoumalo prínos $v$ britském prostředí rozšírených programů lesních škol. Výsledky poukazovaly na možné prínosy tohoto druhu programů na spokojenost žáků, chyběly ale soustavnější evaluační výzkumy (Swarbrick, Eastwood \& Tutton, 2004; Slade, Lowery \& Bland, 2013).

Celkově Ize shrnout, že pro účinnost pobytových terénních programů organizovaných externími subjekty existuje poměrně silná evidence. Programy tohoto typu zpravidla pozitivně posilují znalosti a postoje žáků a mohou mít vliv i na jejich chování. Důležitým faktorem je délka programu. U krátkodobých programů taková evidence chybí a jejich účinnost tedy zůstává nejasná. Málo bývají také hodnoceny dlouhodobé efekty pobytových programů.

\section{Relativní účinnost terénních programů ve srovnání s výukou v učebně}

Relativní účinnost terénních programů oproti stejně zaměřeným programům $v$ učebně naráží na značné metodologické obtíže. Je zjevné, že venkovní prostředí nepředstavuje jedinou nezávisle proměnnou ve srovnávacím experimentu. Do hry nutně vstupují další faktory, jakými mohou být odlišné metody výuky, které venkovní prostředí umožňuje, aspekt novosti prostředí zmiňovaný v několika pracích (Rickinson et al., 2004), odlišné chování skupiny a další faktory.

Nalezené studie můžeme rozdělit do dvou skupin. V první skupině jsou výzkumy dokládající pozitivní efekt terénní výuky na sledované kognitivní, afektivní či konativní oblasti.

Podle Rickinsona et al. (2004) je možné na základě existujících studií předpokládat, že "adekvátně naplánovaná, dobře vyučovaná a efektivně provázaná terénní výuka nabízí žákům více příležitostí k rozvoji jejich znalostí a dovedností, než jejich každodenní zkušenosti v učebně." (s. 24). Podobné vyznění mají i některé další dílčí studie.

Smeds et al. (Smeds \& Jeronen, 2011; Smeds, Jeronen \& Kurppa, 2015) porovnávali tři varianty programu, který měl žáky vést k porozumění "cestě mléka" od farmy po spotřebu. 
$\checkmark$ realizovaném smíšeném výzkumu zaměřeném na znalosti a postoje vyšly jako nejúspěšnější skupiny, které absolvovaly program pouze na farmě nebo na farmě v kombinaci s prací $v$ učebně, oproti žákům, kteři absolvovali práci jenom v učebně. Cachelin, Paisley a Blanchard (2008) porovnávali školní a terénní variantu programu o mokřadech. Podle jejich výsledků měla terénní varianta programu větší dopad na znalosti žáků, obě varianty také vyvolávaly u žáků rozdílné emocionální reakce. Borič a Škugor (2014) ve své evaluaci zjistili, že školní i terénní varianta hodnoceného programu měla srovnatelný dopad na znalosti žáků. Terénní varianta ale účinněji posílila kompetence žáků k řešení problémů. Eaton (2000) ve své studii rozebírá rozdíly v kognitivním vývoji žáků, kteří se účastnili dlouhodobého programu vzdělávání v přírodě, a žáků, kteří trávili školní čas téměř výhradně ve školních učebnách. Studie poukazuje na lepší výsledky dětí, které se účastnily vzdělávání venku. Studie Lieberman a Hoody (1998) zkoumala vliv výuky v přírodě na př́rodovědné znalosti žáků. Žáci, kteří se účastnili dlouhodobé výuky v přírodě, měli v průměru o $27 \%$ lepší výsledky ve standardizovaných testech prírodovědných znalostí než žáci, kteří se o přírodních vědách učili převážně v prostředí školní učebny. Dettmann-Easler a Pease (1999) zjistili při srovnání terénní a interiérové varianty programu o divočině větší a trvalejší dopad terénní varianty na postoje žáků. K podobným výsledkům došli také Fancovičová a Prokop (2011), kteří srovnávali účinnost terénního a interiérového programu o rostlinách. Podle nich se u terénního programu objevil významně vyšší efekt na znalosti a postoje žáků o rostlinách a na zájem o přírodní vědy, než u žáků kontrolní skupiny.

Studií, ve kterých mezi vnitřní a venkovní variantou programu nebyly nalezeny rozdíly, př́padně kdy výuka v učebně byla hodnocena jako účinnější, je výrazně méně. Nejvýznamnější je patrně metastudie Zelezny (1999), která srovnávala osmnáct prací zkoumajících vliv programu na environmentální chování žáků. Podle její analýzy byly školní programy účinnější, než terénní, roli ale hrál také věk žáků a délka programu. $Z$ dílčích studií můžeme uvést práci Gautreau a Binns (2012), kteří porovnávali interiérovou a terénní variantu programu badatelsky orientovaného učení. $\checkmark$ testu ověřujícím znalosti prírodních věd a postoje žáků $k$ vědě nebyly mezi oběma skupinami nalezeny významné rozdíly.

Z důvodu poměrně malého počtu studií porovnávajících terénní programy s jejich interiérovými variantami a současně z důvodu diskutovaných metodologických potiží není zcela snadné vyhodnotit, zda a za jakých podmínek je terénní výuka skutečně účinnější, než výuka v učebně. Přesto se zdá, že studie dokládající vyšší úspěšnost terénní výuky převládají. Můžeme proto předpokládat, že vhodně připravené programy terénní výuky mohou být pro dosažení určitých cílů, např. z oblasti výuky prírodních věd, výchovy ke zdraví, osobnostní a sociální výchovy či environmentální výchovy, účinnější, než tradiční výuka v učebně.

\section{Bariéry implementace terénní výuky na školách}

Důvody pro či proti zavádění terénní výuky na školách je možné vidět v kombinaci referenčního rámce jednotlivých učitelů či vedení školy, s podporou či tlakem sociálního okolí školy, přesvědčením učitelů o zvládnutí terénní výuky (self-efficacy) a dalšími (školami interpretovanými) vnějšími faktory, jako jsou finanční nároky a prostorové a časové bariéry.

Podle Skaugena a Fiskuma (2015) jsou ředitelé škol, které jsou dobře hodnoceny z hlediska studijního prospěchu žáků a současně které zdůrazňují důležitost terénní výuky, přesvědčeni, že terénní výuka je pro školy cestou k vytváření holistického vzdělávacího prostředí. Považují za důležité dát dětem prostor ke hře a ke kontaktu s reálným světem, podporovat jejich fyzickou aktivitu, stimulovat jejich zájem o bádání a rozvíjet sociální kompetence. Analogicky, Remington a Legge (2016) se domnívají, že přičinou malého využívání terénní výuky je nepochopení jejího smyslu. Souvislost s širším vnímáním „smyslu" terénní výuky a způsobem uvažování vedení školy a učitelů o smyslu školní výuky byla patrná také z případových studií českých škol vzorových v oblasti environmentální výchovy (Činčera et al., in press). Důležitým faktorem je vnitřní přesvědčení učitelů a vedení o důležitosti environmentální výchovy a výchovy $v$ př́rodě, míra jejich vlastní environmentální senzitivity a související postoje (Ernest, 2012). 
Dalšími bariérami pak jsou tradice a s nimi související stereotypy v práci školy, ale také špatná príprava učitelů na terénní výuku. Chybějící trénink v realizaci výuky mimo školní zdi považuje za hlavní bariéru také Preston (2015). Špatná př́prava je důvodem nízkého přesvědčení učitelů o vlastních odborných a didaktických schopnostech zvládnout terénní výuku, včetně napríklad jejích bezpečnostních rizik (Rickinson, et al., 2004; Remington \& Legge, 2016; Dallat, Salmon, \& Goode, 2015). Dyment (2005) ve své studii k bariérám bránícím uplatňování terénní výuky zdůrazňuje právě obavy učitelů o bezpečnost žáků v mimoškolním prostředí, které je ve srovnání se školní učebnou podstatně méně předvídatelné a kontrolovatelné. $V$ českém prostředí pak Smetáčková (2011) spatřuje hlavní příčiny klesajícího zájmu o školy v přírodě ve vnějších faktorech, jako jsou ubývající finanční prostředky. Někteří respondenti ve výzkumu Činčera et al. (in press) dále poukazovali na chybějící časový prostor (zejména krátké vyučovací hodiny), tlak na výkon a administrativní požadavky spojené $s$ bezpečností žáků. Rickinson et al. (2004) v souvislosti s důrazem na výkon zmiňuje problematiku požadavků na obsahy školního kurikula. Př́lišná přeplněnost kurikula vzdělávacím obsahem neposkytuje dostatek prostoru k uplatňování výuky v terénu.

\section{Diskuse}

Na základě našeho shrnutí Ize předpokládat, že dobře realizovaná terénní výuka může pomoci naplnit řadu cílů korespondujících se základními vzdělávacími oblastmi i prưřezovými tématy rámcových vzdělávacích programů. Patrně nejdůležitější jsou její prínosy pro výuku prírodovědných předmětů, kde pozitivní dopady na znalosti, postoje $k$ př́rodním vědám a související dovednosti uváděla celá řada analyzovaných studií. Z oblasti výchov pak specifické postavení má environmentální výchova, dále výchova ke zdravému živému stylu a sociálně osobnostní výchova. Terénní programy dále mohou přispět $k$ posílení vztahu $k$ místu, zlepšení vzájemných vztahů ve tř́́dě ( $v$ př́padě komunitně zaměřených projektů) a mohou mít měřitelný dopad na stav místní komunity a životního prostředí.

Nabízí se otázka, jaké jsou „esenciální“ rysy venkovního prostředí, které posilují účinnost terénních programů. Často uváděným motivem je "opravdovost" či "autenticita" výuky ve venkovním prostředí (Smeds, Jeronen \& Kurppa, 2015; Skaugen \& Fiskum, 2015; The Real World Learning, 2015). Takové zdůvodnění ale může být částečně problematizováno: je zapojení žáků do zahradnické práce pod vedením učitele skutečně autentickou zkušeností zahradníka, který se v opravdovém životě rozhoduje na základě vlastní motivace, odpovědnosti a potřeb? Do jaké míry jsou autentické aktivity dobrodružné výchovy, využívající dobrodružné hry jako formu metafory odkazující k "opravdovým" situacím? Proč by učení se ve třídě, kde žáci také zažívají emoce, radují se či pláčou, mělo být méně autentické, než v lese?

Kovalik a Olsen (1994) uvádí jako argument na podporu zkušenostního učení v autentickém prostředí zapojení „všech smyslů" do procesu učení, na rozdíl od kontextu školní výuky, ve kterém žáci výrazně aktivují především zrak a sluch. Kirschner, Sweller a Clark (2006) na druhé straně uvádí, že právě velký přísun informací ve smyslově bohatém venkovním prostředí může na žáky působit rušivě a komplikovat jejich snahu vyznat se $v$ proudu prožitku a přetavit jej do procesu učení. Mechanismy úspěšného transferu mohou být značně náročné a zahrnovat řadu dalších faktorů, jako je skupinová dynamika, lektorské dovednosti učitele, rysy samotného prostředí, vlastnosti probíraného konceptu a další (Sibthorp, 2011). Jejich zvládnutí klade na učitele specifické nároky, na které zřejmě učitelé nejsou dosud zcela připraveni (Remington \& Legge, 2016; Preston, 2015).

Analýza dále ukázala význam řady kontextuálních faktorů, které relativizují jinak poměrně přesvědčivou evidenci úspěšnosti terénní výuky. Je zřejmé, že účinnost programu terénní výuky záleží na jejím provedení a délce jejího trvání. $Z$ tohoto úhlu pohledu se jako nejúčinnější ukazují dlouhodobější programy, které kombinují či provazují terénní výuku s prací ve škole (Rickinson et al., 2004; Orion \& Hoffstein, 1994). To otevírá otázku ostrosti hranic mezi terénní výukou a výukou v učebně. Přikláníme se k názoru Zinka a Burrowse (2008), kteří doporučují nechápat výuku "uvnitř̆" a "venku" jako dva oddělené světy. Výuka ve venkovním prostředí otevírá specifické možnosti, které mohou, ale i nemusejí být využity, stejně jako tomu je při výuce v učebně. Jakkoliv ne- 
chceme význam těchto možností snižovat, úspěšnost programu v rozhodující míře určuje souhra mezi jeho kvalitou, výkonem lektora a vstupní motivací a kompetencemi žáků. Prostředí může být silným, ale pouze jedním z hráčů na tomto hřišti.

Terénní výuka by se proto měla stát přirozenou součástí výuky a měla by být zahrnuta i do př́pravy budoucích učitelů. $Z$ výše uvedených důvodů doporučujeme nechápat ji ani jako marginální, ani jako všespásný přistup k výchově a vzdělávání, ale jako jedno z přirozených prostředí, ve kterých výchova a výuka probíhá. Na místo ostrých hranic doporučujeme hranice rozmazané a na místo programů, které jsou pouze "uvnitř" či jenom „venku" doporučujeme programy "smíšené“, "uvnitř" a "vně" přirozeně kombinující. Metodika takových programů by měla vycházet z př́stupů, které takové „rozmazávání" umožňují. Příkladem takového přístupu je dánský koncept vzdělávání "udeskole", ve kterém je výuka $v$ prírodním prostředí blízkého okolí školy integrovanou součástí školního kurikula. Výukové aktivity v terénu v rámci ,,udeskole“ jsou realizovány na pravidelné bázi a je pro ně charakteristické, že využívají přírodního prostředí jako hlavního nástroje k dosažení výchovně-vzdělávacích cílů v konkrétních předmětech a vzdělávacích oblastech (Bentsen et al., 2010). Rovněž skotské národní kurikulum (Curriculum for Excellence) podporuje výuku ve venkovním prostředí v souvislosti se zvýšením kvality výuky realizované ve školní tř́dě (Brown, 2010). $\checkmark$ České republice je takový př́stup do určité míry zastoupen např. v metodických pracích pro výuku geografie (Řezníčková et al., 2008) či v některých programech koordinovaných centry environmentálního vzdělávání. Žáci pak například mohou prokládat práci ve škole s terénními výpravami (program Les ve škole koordinovaný vzdělávacím centrem Tereza), otevřít ve škole téma navazujícího terénního badatelského úkolu (Vyšetřování katastrofy Jizerských hor), nebo zahájit program pobytem v ekocentru a pak pokračovat školní př́pravou navazujícího komunitního projektu (Kořeny, oba poslední programy vede centrum Společnost pro Jizerské hory).

Je pravděpodobné, že kromě rozmazání hranic mezi výukou v učebně a v terénu zažíváme v současné době také propojování obou prostředí se světem datasféry. První výzkumy účinnosti badatelsky orientovaných terénních programů využívajících prvky rozšířené reality či jinou formu podpory mobilních technologií ukazují, že takové propojení bude - alespoň z pohledu rozvíjení přírodovědných znalostí a zájmu žáků - životaschopné a pravděpodobně dále ovlivní podobu terénní výuky (Chiang, Yang, \& Hwang, 2014; Medzini, Meishar-Tel, \& Sneh, 2014; Liu, Tan, \& Chu, 2009). Je zjevné, že analýza pozitivních i negativních aspektů programů kombinujících všechny tři typy prostředí bude představovat specifickou výzvu pro další výzkumné práce.

\section{Závěr}

V rámci studie jsme na základě analýzy nalezených prací zkoumali efektivitu terénní výuky a bariéry jejího většího rozšíření na školách. Programy terénní výuky jsou velmi rozmanité a jejich souhrnné hodnocení je proto obtížné. Ve studii jsme nicméně ( $v$ rámci uvedených limitů) shromáždili evidenci dostačující $k$ doložení potenciálních př́nosů terénní výuky na znalosti, postoje, dovednosti i chování žáků. Přestože některé studie naznačují opak, převládají práce dokládající relativně vyšší efektivitu terénních programů oproti výuce $v$ učebně. Nejdůležitější bariérou je pravděpodobně interpretace smyslu terénní výuky na samotných školách - pokud školy terénní výuku považují za důležitou (at' již specificky pro naplnění konkrétních výukových cílů či obecně jako prostředku korespondujícího s určitou vizí školy), realizují ji navzdory méně podporujícím vnějším podmínkám.

Pro školní praxi dále doporučujeme vyhnout se ostré dichotomii "terén versus učebna" a přijmout raději př́stup přirozeně rozmazávající hranice mezi oběma prostředími.

\section{Literatura}

- American Institutes of Research (2005). Effects of Outdoor Education Programs for Children in California. Sacramento: California Department of Education. 
- Athman Ernst, J., \& Monroe, M. (2004). The effects of environment-based education on students' critical thinking skills and disposition toward critical thinking. Environmental Education Research, 10(4), 507-522. Retrieved from http://www.tandfonline.com/doi/abs/10.1080/1350462042000291038 http://dx.doi.org/10.1080/1350462042000291038

- Bell, B. J., Gass, M. A., Nafziger, C. S., \& Starbuck, J. D. (2014). The State of Knowledge of Outdoor Orientation Programs: Current Practices, Research, and Theory. J ournal of Experiential Education, 37(1), 31-45. Retrieved from http://jee.sagepub.com/lookup/doi/10.1177/1053825913518891 http://dx.doi.org/10.1177/1053825913518891

- Bentsen, P., Jensen, F. S., Mygind, E., \& Randrup, T. B. (2010). The extent and dissemination of udeskole in Danish schools. Urban Forestry \& Urban Greening, 9(3), 235-243. Retrieved from http://linkinghub.elsevier.com/retrieve/pii/S1618866710000130 http://dx. doi.org/10.1016/j.ufug.2010.02.001

- Blair, D. (2009). The Child in the Garden: An Evaluative Review of the Benefits of School Gardening. The J ournal of Environmental Education, 40(2), 15-38. Retrieved from http://www.tandfonline.com/doi/abs/10.3200/JOEE.40.2.15-38 http://dx. doi.org/10.3200//OEE.40.2.15-38

- Bogner, F. (1998). The Influence of Short-Term Outdoor Ecology Education on Long-Term Variables of Environmental Perspective. The J ournal of Environmental Education, 29(4), 1729. Retrieved from http://www.tandfonline.com/doi/full/10.1080/00958969809599124 http://dx.doi.org/10.1080/00958969809599124

- Bogner, F. X., \& Wiseman, M. (2004). Outdoor Ecology Education and Pupil's Environmental Perception in Preservation and Utilization. Science Education Journal, 15(1), 27-48.

- Boric, E., \& Skugor, A. (2014). Achieving Students' Competencies Through Research-Based Outdoor Science Teaching. Croatian Journal of Education-Hrvatski Casopis Za Odgoj I Obrazovanje, 16(1), 149-164.

- Burešová, K. (2007). Učíme se v zahradě. Kněžice: Chaloupky.

- Cachelin, A., Paisley, K., \& Blanchard, A. (2009). Using significant life experience research to inform program evaluation: A case study of The Nature Conservancy's Wings $\&$ Water wetlands education program. J ournal of Environmental Education, 40(2), 2-14. Retrieved from http://www.tandfonline.com/doi/abs/10.3200/JOEE.40.2.2-14 http://dx. doi.org/10.3200//OEE.40.2.2-14

- Ceaser, D. (2012) Our School at Blair Grocery: A Case Study in Promoting Environmental Action Through Critical Environmental Education. The J ournal of Environmental Education, 43(4), 209-226. http://doi.org/10.1080/00958964.2011.637094. Retrieved from http://www.tandfonline.com/doi/abs/10.1080/00958964.2011.637094 http://dx. doi.org/10.1080/00958964.2011.637094

- Cincera, J., \& Kovacikova, S. (2014). Being an EcoTeam Member: Movers and Fighters. Applied Environmental Education \& Communication, 13(4), 37-41. http://dx. doi.org/10.1080/1533015X.2015.972299

- Cincera, J., \& Maskova, V. (2011). GLOBE in the Czech Republic: a program evaluation. Environmental Education Research, 17(4), 499-517. Retrieved from http://www.tandfonline.com/doi/abs/10.1080/13504622.2011.557497 http://dx. doi.org/10.1080/13504622.2011.557497 
- Cincera, J., Johnson, B., \& Kovacikova, S. (2015). Evaluation of a Place-Based Environmental Education Program: From There to Here. Applied Environmental Education \& Communication, 14(3), 178-186. Retrieved from http://www.tandfonline.com/doi/full/10.1080/1533015X.2015.1067580 http://dx.doi.org/10.1080/1533015X.2015.1067580

- Činčera, J. (2011). Rozvoj výzkumných kompetencí žák na základní škole: zkušenosti z evaluace programu o Jizerských horách. Envigogika, 6(3), 1-13. Retrieved from http://www.envigogika.cuni.cz/index.php/Envigogika/article/view/63 http://dx. doi.org/10.14712/18023061.63

- Činčera, J. (2011). Vliv pobytového programu o Jizerských horách na proenvironmentální postoje a hodnoty. Envigogika, 6(3), 1-16. Retrieved from http://www.envigogika.cuni.cz/index.php/Envigogika/article/view/64 http://dx.doi.org/10.14712/18023061.64

- Činčera, J. (2012). Evaluace orientovaná na uživatele: zkušenosti s pobytovým programem Člověk a prostředí. Orbis Scholae, 6(3), 119-134.

- Činčera, J. (2013). Vliv pobytového programu na atraktivitu J izerských hor. Envigogika, 8(1), 1-10. Retrieved from http://www.envigogika.cuni.cz/index.php/Envigogika/article/view/8 http://dx. doi.org/10.14712/18023061.8

- Činčera, J. (2015) Centra environmentálního vzdělávání z pohledu učitelů. In Účinnost institucionální podpory center environmentálního vzdęlávání. Praha: BEZK; SEVER; Agentura Koniklec. Zprava z projektu.

- Činčera, J. (2015). Využití modelu RWL pro evaluaci pobytového programu. Envigogika, 10(3), 1-14. Retrieved from http://www.envigogika.cuni.cz/index.php/Envigogika/article/view/499 http://dx. doi.org/10.14712/18023061.499

- Činčera, J., \& Macháčková, P. (2009). Evaluace pobytového programu Podblanického ekocentra. Envigogika, 4(3), 1-17. Retrieved from http://www.envigogika.cuni.cz/index.php/Envigogika/article/ view/42 http://dx.doi.org/10.14712/18023061.42

- Činčera, J., Jančaříková, K., Matějček, T., Šimonová, P., Bartoš, J., Lupač, M., \& Broukalová, L. (in press). Environmentální výchova na českých školách. Brno: Masarykova univerzita; BEZK; Agentura Koniklec.

- Dallat, C., Salmon, P. M., \& Goode, N. (2015). All about the Teacher, the Rain and the Backpack: The Lack of a Systems Approach to Risk Assessment in School Outdoor Education Programs. Procedia Manufacturing, 3, 1157-1164. Retrieved from http://linkinghub.elsevier.com/retrieve/pii/S2351978915001948 http://dx.doi.org/10.1016/i.promfg.2015.07.193

- Dettmann-Easler, D., \& Pease, J. L. (1999). Evaluating the effectiveness of residential environmental education programmes in fostering positive attitudes towards wildlife. Journal of Environmental Education, 13(1), 33-9. Retrieved from http://www.tandfonline.com/doi/abs/10.1080/00958969909598630 http://dx.doi.org/10.1080/00958969909598630

- Dostál, J. (2015) Badatelsky orientovana vyuka: pojeti, podstata, vyznam a prinosy. In Badatelsky orientovaná výuka: Pojetí, podstata, význam a př́nosy. Olomouc: Univerzita 
Palackého v Olomouci. Retrieved from

http://doivup.upol.cz/doi/10.5507/pdf.15.24443935.html

http://dx.doi.org/10.5507/pdf.15.24443935

- Duffin, M., Powers, A., \& Tremblay, G. (2004). Place-based Education Evaluation Collaborative $(\mathrm{PEEC})$ : Report on cross-program research and other program evaluation activities 2003--2004. : PEER Associates.

- Dyment, J. E. (2005). Green school grounds as sites for outdoor learning: Barriers and opportunities. International Research in Geographical \& Environmental Education, 14(1), 2845. Retrieved from http://www.tandfonline.com/doi/abs/10.1080/09500790508668328 http://dx.doi.org/10.1080/09500790508668328

- Eaton, D. (2000). Cognitive and affective learning in outdoor education (online). Ontario Institute for Studies in Education of the University of Toronto. Retrieved from http://www.collectionscanada.gc.ca/obj/s4/f2/dsk1/tape10/PQDD_0005/NQ41587.pdf

- Emmons, K. M. (1997). Perceptions of the Environment while Exploring the Outdoors: a case study in Belize. Environmental Education Research, 3(3), 327-344. Retrieved from http://www.tandfonline.com/doi/abs/10.1080/1350462970030306 http://dx.doi.org/10.1080/1350462970030306

- Erdoǧan, M. (2011). The effects of ecology-based summer nature education program on primary school students' environmental knowledge, environmental affect and responsible environmental behavior. Kuram ve Uygulamada Egitim Bilimleri, 11(4), 2233-2237.

- Erdogan, M. (2015). The effect of summer environmental education program (SEEP) on elementary school students' environmental literacy. International J ournal of Environmental and Science Education, 10(2), 165-181. http://dx.doi.org/10.12973/ijese.2015.238a

- Erdogan, M., Uşak, M., \& Bahar, M. (2013). A Review of research on environmental education in non-traditional settings in Turkey, 2000 and 2011. International J ournal of Environmental and Science Education, 8(1), 37-57.

- Ernst, J. (2012). Influences on and Obstacles to K-12 Administrators' Support for Environment-Based Education. The J ournal of Environmental Education, 43(2), 73-92. Retrieved from http://www.tandfonline.com/doi/abs/10.1080/00958964.2011.602759 http://dx.doi.org/10.1080/00958964.2011.602759

- Fančovičová, J., \& Prokop, P. (2011). Plants have a chance: outdoor educational programmes alter students' knowledge and attitudes towards plants. Environmental Education Research, 17(4), 537-551. Retrieved from http://www.tandfonline.com/doi/abs/10.1080/13504622.2010.545874 http://dx.doi.org/10.1080/13504622.2010.545874

- Ferreira, S. (2012). Moulding urban children towards environmental stewardship: the Table Mountain National Park experience. Environmental Education Research, 18(2), 251-270. Retrieved from http://www.tandfonline.com/doi/abs/10.1080/13504622.2011.622838 http://dx.doi.org/10.1080/13504622.2011.622838

- Fisher-Maltese, C., \& Zimmerman, T. D. (2015). A garden-based approach to teaching life science produces shifts in students' attitudes toward the environment. International J ournal of Environmental and Science Education, 10(1), 51-66. http://dx.doi.org/10.12973/ijese.2015.230a

- Fleszar, E., \& Gwardys-Szczęsna, S. (2009). The School Gardens in Preserving Biological Diversity for Education of Sustainable Development. Bulgarian Journal of Science \& Education Policy, 3(2), 216-232. 
- Fox, K. R. (2010). Children Making a Difference: Developing Awareness of Poverty Through Service Learning. The Social Studies, 101(1), 1-9. Retrieved from http://www.tandfonline.com/doi/abs/10.1080/00377990903283965 http://dx.doi.org/10.1080/00377990903283965

- Gautreau, B. T., \& Binns, I. C. (2012). Investigating Student Attitudes and Achievements in an Environmental Place-Based Inquiry in Secondary Classrooms. International J ournal of Environmental and Science Education, 7(2), 167-195.

- Gruenewald, D. (2008). The best of both worlds : a critical pedagogy of place. Educational Researcher, 32(4), 3-12. http://dx.doi.org/10.1080/13504620802193572

- Harrison, S. (2011). "Up at the Shieling": Place-Based Action Research. Children Youth and Environments, 21(1), 1. http://dx.doi.org/10.7721/chilyoutenvi.21.1.0079

- Hill, A. (2013). The Place of Experience and the Experience of Place: Intersections Between Sustainability Education and Outdoor Learning. Australian Journal of Environmental Education, 29(01), 18-32. Retrieved from http://www.journals.cambridge.org/abstract_S081406261300013X http://dx.doi.org/10.1017/aee.2013.13

- Hofmann, E., \& Korvas, P. (2008). Terénní výuka s pohybovými aktivitami. Geographia Cassoviensis, 1(47), 47-52.

- Hofmann, E., Trávníček, M., \& Soják, P. (2011) Integrovaná terénní výuka jako systém. In Smíšený design v pedagogickém výzkumu: Sborník př́spěvků z 19. výroční konference České asociace pedagogického výzkumu (pp. 310-315).

- Howley, A., Howley, M., Camper, C., \& Perko, H. (2011). Place-Based Education at Island Community School. The Journal of Environmental Education, 42(4), 216-236. Retrieved from http://www.tandfonline.com/doi/abs/10.1080/00958964.2011.556682 http://dx.doi.org/10.1080/00958964.2011.556682

- Chiang, T. H. C., Yang, S. J. H., \& Hwang, G. J. (2014). An augmented reality-based mobile learning system to improve students' learning achievements and motivations in natural science inquiry activities. Educational Technology and Society, 17(4), 352-365.

- Christidou, V., Tsevreni, I., Epitropou, M., \& Kittas, C. (2013). Exploring primary children's views and experiences the school ground: The case of a Greek school. International J ournal of Environmental and Science Education, 8(1), 59-83.

- Johnson, B., \& Činčera, J. (2015). Examining the Relationship between Environmental Attitudes and Behaviour in Education Programmes. Sociální studia, 3, 97-111.

- Johnson, B., Duffin, M., \& Murphy, M. (2012). Quantifying a relationship between placebased learning and environmental quality. Environmental Education Research, 18(5), 609624. Retrieved from http://www.tandfonline.com/doi/abs/10.1080/13504622.2011.640748 http://dx. doi.org/10.1080/13504622.2011.640748

- Jorgenson, S. (2014). The Logic of School Gardens: A Phenomenological Study of Teacher Rationales. Australian J ournal of Environmental Education, 29(2), 121-135. Retrieved from http://www.journals.cambridge.org/abstract_S0814062614000019 http://dx.doi.org/10.1017/aee.2014.1

- Kirschner, P. A., Sweller, J., \& Clark, R. E. (2006). Why Minimal Guidance During Instruction Does Not Work: An Analysis of the Failure of Constructivist, Discovery, Problem-Based, Experiential, and Inquiry-Based Teaching. Educational Psychologist, 41(2), 75-86. Retrie- 
ved from http://www.tandfonline.com/doi/abs/10.1207/s15326985ep4102_1 http://dx.doi.org/10.1207/s15326985ep4102_1

- Kovalik, S., \& Olsen, K. (1994). ITI: The model. Integrated thematic instruction. Kent: S. Kovalik \& Associates.

- Liberman, G. \& Hoody, L., (1998) Closing the achievement gap: using the environment as an integrating context online. In State Environment and Education Roundtable California, Science Wizards, 1998 [cit. 30. brezna 2013]. Retrieved from http://www.seer.org/extras/execsum.pdf

- Liu, T. Y., Tan, T. H., \& Chu, Y. L. (2009). Outdoor natural science learning with an RFIDsupported immersive ubiquitous learning environment. Educational Technology and Society, 12(4), 161-175. Retrieved from http://ieeexplore.ieee.org/document/5988881 http://dx.doi.org/10.1109/MACE.2011.5988881

- Malone, K., \& Tranter, P. J. (2003). School Grounds as Sites for Learning: Making the most of environmental opportunities. Environmental Education Research, 9(3), 283-303. Retrieved from http://www.tandfonline.com/doi/abs/10.1080/13504620303459 http://dx. doi.org/10.1080/13504620303459

- Mannion, G., Fenwick, A., \& Lynch, J. (2013). Place-responsive pedagogy: learning from teachers' experiences of excursions in nature. Environmental Education Research, 19(6), 792-809. Retrieved from http://www.tandfonline.com/doi/abs/10.1080/13504622.2012.749980 http://dx. doi.org/10.1080/13504622.2012.749980

- Manoli, C. C., J ohnson, B., Hadjichambis, A. C., Hadjichambi, D., Georgiou, Y., \& I oannou, H. (2014). Evaluating the impact of the Earthkeepers Earth education program on children's ecological understandings, values and attitudes, and behaviour in Cyprus. Studies in Educational Evaluation, 41, 29-37. Retrieved from http://linkinghub.elsevier.com/retrieve/pii/S0191491X13000400 http://dx.doi.org/10.1016/j.stueduc.2013.09.008

- Maynard, T., \& Waters, J. (2007). Learning in the outdoor environment: a missed opportunity. Early Years, 27(3), 255-265. Retrieved from http://www.tandfonline.com/doi/abs/10.1080/09575140701594400 http://dx.doi.org/10.1080/09575140701594400

- Medzini, A., Meishar-Tal, H., \& Sneh, Y. (2014). Use of mobile technologies as support tools for geography field trips. International Research in Geographical and Environmental Education, 24(1), 13-23. Retrieved from http://www.tandfonline.com/doi/abs/10.1080/10382046.2014.967514 http://dx.doi.org/10.1080/10382046.2014.967514

- Motallebzadeh, K. (2014). Place-Based Education - Does it Improve 21st Century SkiIls. International J ournal of Applied Linguistics \& English Literature, 4(1), 89-94. http://dx.doi.org/10.7575/aiac.ijalel.v.4n.1p.89

- Muñoz, S. (2009) Children in the Outdoors. In Children in the Outdoors. Literature Review. Forres: Sustaianble Development Research Centre. Retrieved from http://www.educationscotland.gov.uk/I mages/Children\% 20in\%20the\% 20outdoors\%20liter ature\%20review_tcm4-597028.pdf

- Komárka, N. P. K. (2016) České děti venku : Reprezentativní výzkum, kde a jak tráví děti svůj čas. [online] 5. 5. 2016. Dostupne z: Nadace Proměny Karla Komárka. Retrieved from http://www.nadace-promeny.cz/cz/vyzkum.html 
- Nadelson, L. S., \& J ordan, J. Richard, (2012). Student Attitudes Toward and Recall of Outside Day: An Environmental Science Field Trip. The J ournal of Educational Research, 105(3), 220-231. Retrieved from http://www.tandfonline.com/doi/abs/10.1080/00220671.2011.576715 http://dx.doi.org/10.1080/00220671.2011.576715

- Neill, J. T., \& Richards, G. E. (1998). Does Outdoor Education Really Work? A Summary Of Recent Meta-Analyses. Australian J ournal of Outdoor Education, 3(1), 1-9.

- Neuman, J. (2013). Osobnostní rozvoj prostřednictvím učení a výchovy v prírodě. ACORát, 2(1), 47-67.

- Nicol, R. (2003). Outdoor education: Research topic or universal value? Part three. J ournal of Adventure Education \& Outdoor Learning, 3(1), 11-27. Retrieved from http://www.tandfonline.com/doi/abs/10.1080/14729670385200211 http://dx.doi.org/10.1080/14729670385200211

- Ontong, K., \& Le Grange, L, (2015). The need for place-based education in South African schools: The case of Greenfields Primary. Perspectives in Education, 33(3), 42-57. Retrieved from http://www. scopus.com/inward/record.url?eid=2-s2.084945947104\&partnerl $\mathrm{D}=40 \& \mathrm{md} 5=\mathrm{a} 7038260 \mathrm{~d} 927 \mathrm{e} 6 \mathrm{beb01ba258 \textrm {cb } 1 9 5 \mathrm { df } 6}$

- Orion, N., \& Hofstein, A. (1994). Factors that influence learning during a scientific field trip in a natural environment. Journal of Research in Science Teaching, 31(10), 1097-1119. Retrieved from http://doi.wiley.com/10.1002/tea.3660311005 http://dx.doi.org/10.1002/tea.3660311005

- Palmberg, I. E., \& Kuru, J. (2000). Outdoor Activities as a Basis for Environmental Responsibility. The J ournal of Environmental Education, 31(4), 32-36. Retrieved from http://www.tandfonline.com/doi/abs/10.1080/00958960009598649 http://dx.doi.org/10.1080/00958960009598649

- Parmer, S. M., Salisbury-Glennon, J., Shannon, D., \& Struempler, B. (2009). School Gardens: An Experiential Learning Approach for a Nutrition Education Program to Increase Fruit and Vegetable Knowledge, Preference, and Consumption among Second-grade Students. J ournal of Nutrition Education and Behavior, 41(3), 212-217. Retrieved from http://linkinghub.elsevier.com/retrieve/pii/S1499404608007008 http://dx. doi.org/10.1016/j.jneb.2008.06.002

- Passy, R. (2014). School gardens: Teaching and learning outside the front door. Education, 42(1), 23-38.

- Pavučina. (2009) Analyza stavu environmentalniho vzdelavani, vychovy a osvety. In Analýza stavu environmentálního vzdèlávání, výchovy a osvěty. Praha: SSEV Pavučina.

- Plaka, V., \& Skanavis, C. (2016). The feasibility of school gardens as an educational approach in Greece : a survey of Greek schools. International J ournal of Innovation \& Sustainable Development, 10(2), 141-159. Retrieved from http://www.inderscience.com/link.php?id $=75546$ http://dx.doi.org/10.1504/IJISD.2016.075546

- Powers, A. L. (2004). An Evaluation of Four Place-Based Education Programs. The Journal of Environmental Education, 35(4), 17-32. Retrieved from http://www.tandfonline.com/doi/abs/10.3200/JOEE.35.4.17-32 http://dx.doi.org/10.3200//OEE.35.4.17-32 
- Preston, L. (2015). The Place of Place-Based Education in the Australian Primary Geography Curriculum. Geographical Education, 28, 41-49. Retrieved from http://login.ezproxy.library.ualberta.ca/login?url=http://search. ebscohost.com/login. aspx? direct $=$ true $\& \mathrm{db}=$ eric $\& A N=E]$ 1085985\&site $=$ eds-live $\&$ scope $=$ site

- Priest, S. (1986). Redefining outdoor education: A matter of many relationships. The J ournal of Environmental Education, 17(3), 13-15. Retrieved from http://www.tandfonline.com/doi/abs/10.1080/00958964.1986.9941413 http://dx.doi.org/10.1080/00958964.1986.9941413

- Priest, S., \& Gass, M. A. (2005). Effective leadership in adventure programming. Champaign, IL: Human Kinetics.

- Remington, T., \& Legge, M. (2016). Outdoor education in rural primary schools in New Zealand: a narrative inquiry. Journal of Adventure Education and Outdoor Learning, 9679, 112. Retrieved from http://www.tandfonline.com/doi/full/10.1080/14729679.2016.1175362 http://dx. doi.org/10.1080/14729679.2016.1175362

- Rickinson, M. (2001). Learners and Learning in Environmental Education: A critical review of the evidence. Environmental Education Research, 7(3), 207-320. Retrieved from http://www.tandfonline.com/doi/abs/10.1080/13504620120065230 http://dx.doi.org/10.1080/13504620120065230

- Rickinson, M., Dillon, J., Teamey, K., Morris, M., Choi, M. Y., Sanders, D., Benefield, P. (2004). A review of research on outdoor learning. National Foundation for Educational Research, King's College London. Retrieved from https://www. field-studiescouncil.org/media/268859/2004_a_review_of_research_on_outdoor_learning.pdf

- Ruiz-Gallardo, J., Verde, A., \& Valdés, A. (2013). Garden-Based Learning: An Experience With "At Risk" Secondary Education Students. The J ournal of Environmental Education, 44(4), 252-270. Retrieved from http://www.tandfonline.com/doi/abs/10.1080/00958964.2013.786669 http://dx.doi.org/10.1080/00958964.2013.786669

- Rye, J. A., Selmer, S. J., Pennington, S., Vanhorn, L., Fox, S., \& Kane, S. (2012). Elementary School Garden Programs Enhance Science Education for All Learners. TEACHING Exceptional Children, 44(6), 58-65. Retrieved from http://tcx.sagepub.com/lookup/doi/10.1177/004005991204400606 http://dx.doi.org/10.1177/004005991204400606

- Řezníčková, D., Kučerová, S., Marada, M., Matějček, T., Šefrna, L., \& Vočadlová, K. (2008): Náměty pro geografické a environmentální vzdělávání. Výuka v krajině. Univerzita Karlova, Praha: Univerzita Karlova.

- Semken, S. (2005). Sense of Place and Place-Based Introductory Geoscience Teaching for American Indian and Alaska Native Undergraduates. J ournal of Geoscience Education, 53(2), 149-157. Retrieved from http://nagt-jge.org/doi/10.5408/1089-9995-53.2.149 http://dx. doi.org/10.5408/1089-9995-53.2.149

- Sibthorp, J., Furman, N., Paisley, K., Gookin, J., \& Schumann, S. (2011). Mechanisms of Learning Transfer in Adventure Education: Qualitative Results From the NOLS Transfer Survey. Journal of Experiential Education, 34(2), 109-126. Retrieved from http://aee. metapress.com/openurl.asp? genre=article\&id=doi: 10.5193/JEE34.2.109 http://dx.doi.org/10.5193/JEE34.2.109

- Skaugen, R., \& Fiskum, T. A. (2015). How Schools with Good Academic Results J ustify Their Use of Outdoor Education. International Education Research, 3(4), 16-31. Retrieved from 
http://www.todayscience.org/ierarticle?paper_id=527300044

http://dx. doi.org/10.12735/ier.v3i4p16

- Skinner, E. A., Chi, U., \& The Learning-Gardens Educational Assesment Group. (2012). Intrinsic Motivation and Engagement as Active Ingredients in Garden-Based Education: Examining Models and Measures Derived From Self-Determination Theory. The J ournal of Environmental Education, 43(1), 16-36. http://doi.org/10.1080/00958964.2011.596856.

- Slade, M., Lowery, C., \& Bland, K. E. N. (2013). Evaluating the impact of Forest Schools: a collaboration between a university and a primary school. Support for Learning, 28(2), 6672. Retrieved from http://doi. wiley.com/10.1111/1467-9604.12020 http://dx. doi.org/10.1111/1467-9604.12020

- Smeds, P., Jeronen, E., Kurppa, S., \& Vieraankivi, M. (2011). Rural camp school eco learnOutdoor education in rural settings. International J ournal of Environmental and Science Education, 6(3), 267-291. Retrieved from http://ijese.com/IJESE_v6n3_Smeds-et-al.pdf

- Smeds, P., Jeronen, E., \& Kurppa, S. (2015). Farm education and the value of learning in an authentic learning environment. International J ournal of Environmental and Science Education, 10(3), 381-404. http://dx.doi.org/10.12973/ijese.2015.251a

- Smetáčková, I. (2011). Škola v prírodě: limity a dilemata. Pedagogická orientace, 21(4), 416-435.

- Smith, G. A. (2007). Place-based education: breaking through the constraining regularities of public school. Environmental Education Research, 13(2), 189-207. Retrieved from http://www.tandfonline.com/doi/abs/10.1080/13504620701285180 http://dx.doi.org/10.1080/13504620701285180

- Sobel, D. (2005). Place-Based Education: Connecting Classrooms \& Communities. Barrington: The Orion Society.

- Stern, M. J., Powell, R. B., \& Ardoin, N. M. (2008). What Difference Does It Make? Assessing Outcomes From Participation in a Residential Environmental Education Program. The J ournal of Environmental Education, 39(4), 31-43. Retrieved from http://www.tandfonline.com/doi/abs/10.3200/JOEE.39.4.31-43 http://dx. doi.org/10.3200//OEE.39.4.31-43

- Stevenson, K. T., Peterson, N. M., Carrier, S. J., Strnad, R. L., Bondell, H. D., KirbyHathaway, T., \& Moore, S. E. (2014). Role of Significant Life Experiences in Building Environmental Knowledge and Behavior Among Middle School Students. The J ournal of Environmental Education, 45(3), 163-177. Retrieved from http://www.tandfonline.com/doi/abs/10.1080/00958964.2014.901935 http://dx. doi.org/10.1080/00958964.2014.901935

- Swarbrick, N., Eastwood, G., \& Tutton, K. (2004). Self-esteem and successful interaction as part of the forest school project. Support for Learning, 19(3), 142-146. Retrieved from http://doi. wiley.com/10.1111/j.0268-2141.2004.00337.x http://dx. doi.org/10.1111/j.0268-2141.2004.00337.x

- World, L. (2015) Real world learning model. Retrieved from http://www.rwlnetwork. org/rwl-model. aspx

- Thomson, S. (2007). Do's and don'ts: children's experiences of the primary school playground. Environmental Education Research, 13(4), 487-500. Retrieved from http://www.tandfonline.com/doi/abs/10.1080/13504620701581588 http://dx.doi.org/10.1080/13504620701581588 
- Vácha, Z. (2015). Didaktické využití školních zahrad v České republice na primárním stupni základních škol. SciEd, 6(1), 80-90.

- Van Matre, S. (1999). Earth Education: a new beginning. Greenville: The Institute for Earth Education.

- Zelezny, L. C. (1999). Educational Interventions That Improve Environmental Behaviors: A Meta-Analysis. The Journal of Environmental Education, 31(1), 5-14. Retrieved from http://www.tandfonline.com/doi/abs/10.1080/00958969909598627 http://dx.doi.org/10.1080/00958969909598627

- Zink, R., \& Burrows, L. (2008). 'Is what you see what you get?' The production of knowledge in-between the indoors and the outdoors in outdoor education. Physical Education \& Sport Pedagogy, 13(3), 251-265. Retrieved from http://www.tandfonline.com/doi/abs/10.1080/17408980701345733 http://dx.doi.org/10.1080/17408980701345733

- Žák, M. (2011). Jaký má vliv úvodní soustředění (nebo-li adaptační kurz) na kvalitu sociálních vztahů ve tř́lním kolektivu. Gymnos Akadémos, 1(2), 28-42. 